\title{
Kemény Ferencre emlékezve
}

Mezőkövesd, 1944. 07. 09. - Budapest, 2020. 04. 15.

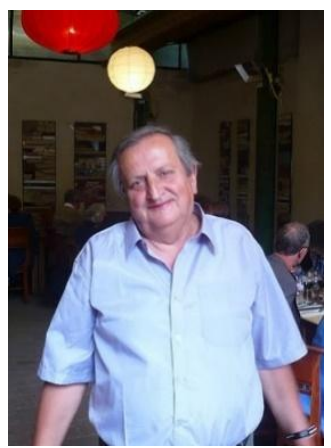

1966-ban sok iskolapadból érkező, izguló fiatal között ültem a Bárczi felvételi vizsgáján és igyekeztem magabiztosnak mutatni magam néhány hányatott évvel a hátam mögött, amikor lehuppant mellém egy rendíthetetlen nyugalmat árasztó, velem egykorúnak tűnő fiú, aki komótosan írogatott a felvételire kiosztott papíron, mialatt én próbáltam erőt meríteni nyugalmából. Akkor még nem sejthettem, hogy sok éven keresztül utunk közös lesz. Az évfolyamnak, amelybe kerültünk hasonlóan hozzánk sok olyan hallgatója volt, aki a felvételi előtt sok mindent kipróbált, és még mindig kereste útját. Feri a föiskolai tanulmányai előtt fényképész-optikus képesítést szerzett és az OFOTÉRT-nál dolgozott. Ez közrejátszott abban, hogy már a föiskolai évek alatt tanszéki technikus lett a Kórtani Tanszéken, ahol olyan neves szakemberek voltak, mint a nemzetközi hírü filmes és fotográfus Vadász János, a hazai kutatólaboratóriumi mikrofotográfia kiemelkedő egyénisége. Feri a tanszéken egyre több feladatot kapott, majd a föiskola befejezése után oktatástechnikát kezdett tanítani, miközben a Kórtani Tanszék vezetője - dr. Göllesz Viktor - hatására érdeklődése egyre inkább a felnőtt fogyatékosok rehabilitációja felé fordult. A sors úgy hozta, hogy közben együtt tanultunk az ELTE pszichológia szakán, majd utunk egy időre szétvált, én pszichiátriai területen dolgoztam, ő pedig a főiskolai képzésben Göllesz Viktor egyik legközelebbi munkatársa lett. Ezeknek az éveknek szakmai életútjában meghatározó szerepe volt, és amikor dr. Göllesz Viktor a föiskola főigazgatójaként kezdeményezte a felnőtt fogyatékosok rehabilitációjára és életviteli támogatására felkészítő szociális szervező képzés létrehozását, a képzési program kidolgozásában és a képzés idősellátás területére kiterjesztésében Feri kulcsszerepet játszott, majd e szak tanszékvezetője lett. Az 1973-ban létrejött szociális szervező képzésről annak 45. évfordulója kapcsán a közelmúltban megemlékeztünk, és írtunk szerepéről, jelentőségéről a szociális képzések kapcsán. Itt most visszatekintve elsősorban Feri személyes hatásáról, és arról a szoros és kölcsönös szakmai és emberi kapcsolatról írnék, amely őt és tanítványait hosszú éveken keresztül összekötötte. Ez egy olyan munka melletti képzés volt, ahová terepről érkező, ambiciózus, sokat látott és próbált emberek érkeztek, és sokan közülük „első generációs” értelmiségiként váltak a terület meghatározó szakembereivé. Számukra a föiskolai tanulás hatalmas lépés volt, ugyanakkor egy olyan szakmai közösségre is találtak, amelyhez egy életre kötődtek. Az, hogy ez az iskola ilyenné vált számukra nagyban Ferinek is köszönhető volt, aki ismerte világukat és problémáikra, kérdéseikre hiteles válaszokat tudott adni, ugyanakkor közel állt hozzájuk nyitottságával, emberi közvetlenségével, humorával és mély emberségével. Nagyon szeretett ebben a képzésben tanítani, és otthon érezte magát akár a tanteremben, akár az intézményekben, ahol gyakran megfordultunk. A képzés 15 éve szakmai pályafutásának legszebb korszaka volt. A képzési modellváltás és a szociális munkás képzés megjelenése a Bárczin számunkra komoly kihívás volt, és bár figyelemmel és szakmai 
tudásában felkészülten fordult a nappali képzésben résztvevő diákok felé, nagyon hiányzott neki a terepről jövők munka melletti képzése, ahol igazán otthon érezte magát. A diákok szerették közvetlenségét, humorát, emberségét és gyakorlatközeli tudását. A váltás érzelmileg is bonyolult időszakában hihetetlenül kollegiális és szolidáris volt az újraszerveződő tanszékkel, és az érkező új munkatársakkal is. A hosszú évek alatt nem emlékszem olyanra, hogy bárkinek is konfliktusa lett volna vele. Mindig számítani lehetett rá. Számára szakmai pályafutásának második felében az élet ajándéka volt a szociális menedzser képzés létrejötte, ahol igazán újra magára talált egy olyan munka melletti képzésben, ahol kollégákkal dolgozhatott, és akik között nagy arányban a szociális szervező képzésből már ismert régi tanítványokkal találkozhatott újra. Nagyon lelkes volt, és az ott tanító oktatókkal egy új szakmai közösségre talált. Erről a korszakról, és barátságukról a szociális menedzser képzés létrehozásában kulcsszerepet játszó Hegyesi Gábor tud leghitelesebben beszámolni.

Az egyetemi integráció és a képzés áttelepülése az ELTE Társadalomtudományi Karára pályafutása késői szakaszában új kihívást jelentett, amely során újra tapasztalhattuk rendíthetetlen nyugalmát és támogató jelenlétét. Nyugdíjba menetele után még egy ideig köztünk volt, és tanított a Wesley képzésében is, de a rárontó súlyos betegségek nyomán jelenléte a képzésben váratlanul és fájdalmasan gyorsan véget ért. Ez ugyanúgy felkészületlenül ért minket, mint halála. Amikor ezeket a sorokat írom és visszatekintek a több mint ötvenéves közös múltunkra, és arra a harminc évnél hosszabb időszakra, ami alatt legtöbbször közös munkában közös szobát megosztva töltöttük időnket, sokszor felmerül bennem, hogy mit is hagyott ránk és mire tanított minket. Oktatóként a szakma gyakorlatához közeli szemléletet és tudást közvetítette képzésünk szempontjából nélkülözhetetlen tudást és mintát nyújtva tanítványainak. Emberi kvalitásai és az általa képviselt értékek pedig jelentős mértékben hozzájárultak szakmai generációk neveléséhez, és a szakmai kultúra erősítéséhez. Példát mutatott nekünk szolidaritásról, önzetlenségről is, és arról a ritka emberi tulajdonságról, hogy hiányzott belőle a hiúságra, irigységre és rivalizációra való hajlam. Kemény Ferenc ny. föiskolai docens 76 évet élt. Sokan szeretettel és tisztelettel őrizzük emlékét. 